Proc. Estonian Acad. Sci. Geol., 2003, 52, 3, 135-154

\title{
The stratotype of the Orasoja Member (Tremadocian, Northeast Estonia): lithology, mineralogy, and biostratigraphy
}

\author{
Heljo Heinsalu $^{\mathrm{a}}$, Dimitri Kaljo ${ }^{\mathrm{a}}$, Tiia Kurvits ${ }^{\mathrm{b}}$, and Viive Viira ${ }^{\mathrm{a}}$ \\ ${ }^{a}$ Institute of Geology at Tallinn Technical University, Estonia pst. 7, 10143 Tallinn, Estonia; \\ heinsalu@hot.ee,kaljo@gi.ee, viira@gi.ee \\ b Institute of Geology, University of Tartu, Vanemuise 46, 51014 Tartu, Estonia; Tiia.Kurvits@ut.ee
}

Received 9 June 2003

\begin{abstract}
The Orasoja Member constitutes in Northeast Estonia the upper part of the Kallavere Formation and forms some kind of transition into the Türisalu Formation. The member belongs to the Lower Ordovician part (Karepa Substage) of the Pakerort Stage. The Orasoja Member is composed of alternating beds of light quartzose siltstone and black shale. The share of shale is cyclically variable, but mainly siltstone is prevailing. Mineralogically quartz is dominant, K-feldspar (up to 15\%) forming a minor component of the rock. Mineral and grain size composition allows us to distinguish two fairly distinct cycles in the Orasoja Member, which are in correlation with changes in conodont associations. Three conodont biozones are distinguished in the section: Cordylodus proavus, C. lindstromi, and C. angulatus. The first appearance of Iapetognathus sp. in the Rannu Member is interpreted here as indicating the beginning of the Ordovician System. Graptolite occurrences give evidence of the presence of the Rhabdinopora flabelliformis socialis and $R$. f. anglica subzones. Earlier dendroids are missing, but this is mainly attributed to a taphonomical bias.
\end{abstract}

Key words: conodonts, graptolites, stratigraphy, lithology, mineralogy, Lower Ordovician, Estonia.

\section{INTRODUCTION}

The North Estonian Klint area (Fig. 1) with its magnificent exposures continuedly serves for discussion of different aspects of the Baltic early Palaeozoic geology, including economic geology of the phosphorites at the CambrianOrdovician boundary and many topics in lithology, stratigraphy, etc. of the stages called in Estonian "Klint stages" (lower and middle Ordovician stages cropping out in the Klint). Professor Karl Orviku was a great researcher of the Klint stages and therefore we are pleased to publish our paper, closely tied to the Klint area, in the issue of the Proceedings dedicated to his memory. 


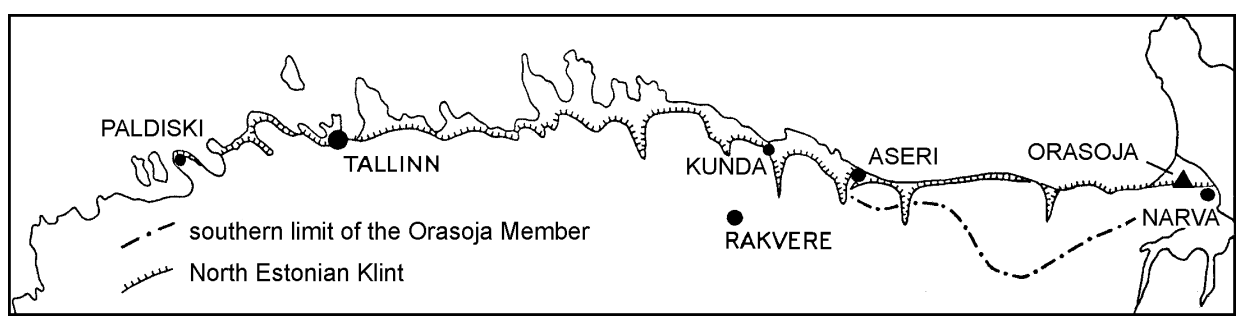

Fig. 1. North Estonian Klint area: location of the stratotype and distribution area of the Orasoja Member.

Stratigraphy of the upper part of the early Palaeozoic clastic sedimentary rocks forming the foot of the Klint is rather complicated (Fig. 2). The Pakerort Regional Stage and its lower part, the Kallavere Formation, including the Orasoja Member dealt with in detail below, represent the transition through the Cambrian-Ordovician boundary, with a specific sequence of rocks and fossils significant for understanding the geological history of the area. Puura \& Viira (1999), introducing the Vihula Substage for the Cambrian part and the Karepa Substage for the Ordovician part of the Pakerort Regional Stage, tried to make chronostratigraphy of the interval easier for use. In lithostratigraphy the Kallavere Formation is subdivided into five members (Fig. 2): Maardu, Suurjõgi, and Katela in the central and western parts of North Estonia (west of the KundaRakvere line, Fig. 1), and Rannu and Orasoja in NE Estonia (Heinsalu 1987).

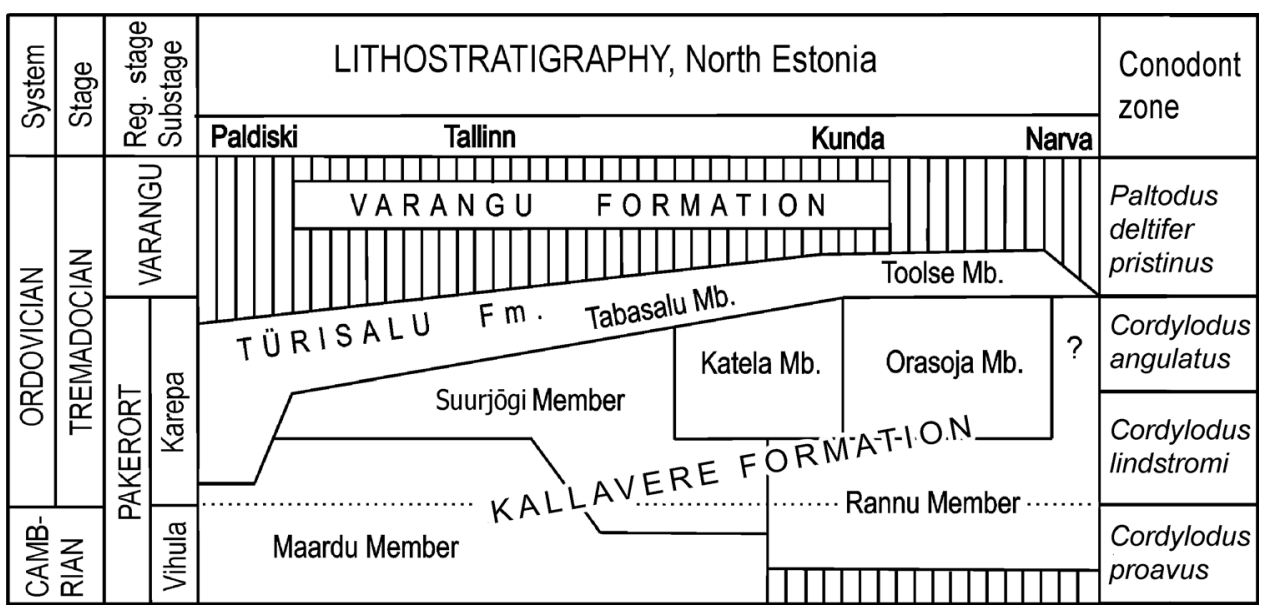

Fig. 2. Stratigraphical classifications of the Lower Tremadocian and adjacent rocks of North Estonia. Modified from Heinsalu (1987), with supplements from Heinsalu \& Raudsep (2000) and the new graptolite information incorporated. Conodont zones according to Kaljo et al. (1986), here revised by V. Viira. 
The Orasoja Member was established by Loog (1964), although the name "Orasoja Beds" was used but not published earlier by K. Müürisepp. The name was applied to a transition between the Dictyonema Shale (with many interbeds of quartzose sandstone in the lower part) of the Türisalu Formation and the Obolus Sandstone represented in NE Estonia. The Orasoja Member is distributed in a relatively limited area along the North Estonian Klint east of Aseri (Fig. 1). Practically everywhere the member underlies the Türisalu Formation and overlies the Rannu Member (Fig. 2), and only southeast and east of the belt the latter member fills (perhaps with a gap in the top) the whole interval up to the Dictyonema Shale.

The stratotype section of the Orasoja Member on the right steep bank of the Orasoja Brook in Puhkova village, about $10 \mathrm{~km}$ west of Narva town was first selected and described by Loog \& Kivimägi (1968). This is the easternmost outcrop of the member in Estonia. Eastwards, in NW Russia, analogous rocks are not known in the Tosna Formation, but have been established in the lower part of the Koporye Formation at the Lomashka River and in its neighbourhood in the west of the Leningrad Region (Kaljo et al. 1986; Popov et al. 1989). The Orasoja Member has been treated in several papers, but in greatest detail in Heinsalu \& Raudsep (2000), where data about lithology and the $\mathrm{P}_{2} \mathrm{O}_{5}$ content in the type section are presented.

Despite its very limited distribution, the Orasoja Member, with specific alternation of muddy and sandy lithologies and sufficiently rich assemblages of biostratigraphically valuable conodonts and several dendroid graptolites, is a significant unit for understanding the geological history of the area. Bearing these aspects in mind, we pursue two main tasks: first, to compile a detailed lithological, mineralogical, and biostratigraphical description of the stratotype section and second, to evaluate these data for the Tremadocian stratigraphy and basin evolution in Estonia. Some earlier conclusions on the Cambrian-Ordovician boundary in Estonia will be also revised and commented on.

This study was commenced several years ago within the framework of different projects, but for this paper the results were summarized by the current team of authors. Responsibilities were shared as follows: H. H. - coordination, lithology; D. K. - graptolites, biostratigraphy; T. K. - mineralogy, grain size analysis, and V. V. - conodonts, biostratigraphy. Collections of conodonts and graptolites studied are deposited in the Institute of Geology at Tallinn Technical University (GIT). The illustrated specimens form the collection GIT 390.

\section{MACROLITHOLOGICAL DESCRIPTION OF THE ORASOJA SECTION}

The outcrop shows a 4-5 $\mathrm{m}$ thick succession of sedimentary rocks beginning with the early Cambrian Tiskre sandstone and ending with the glauconitic sandstone of the Leetse Formation (Arenig) in the upper part of the outcrop. The description below is given from top to base, beginning with the Türisalu Formation (Fig. 3); details on lithology, mineralogy, and fossil content are included into next chapters. For every unit described the number of the bed, thickness, and list of 


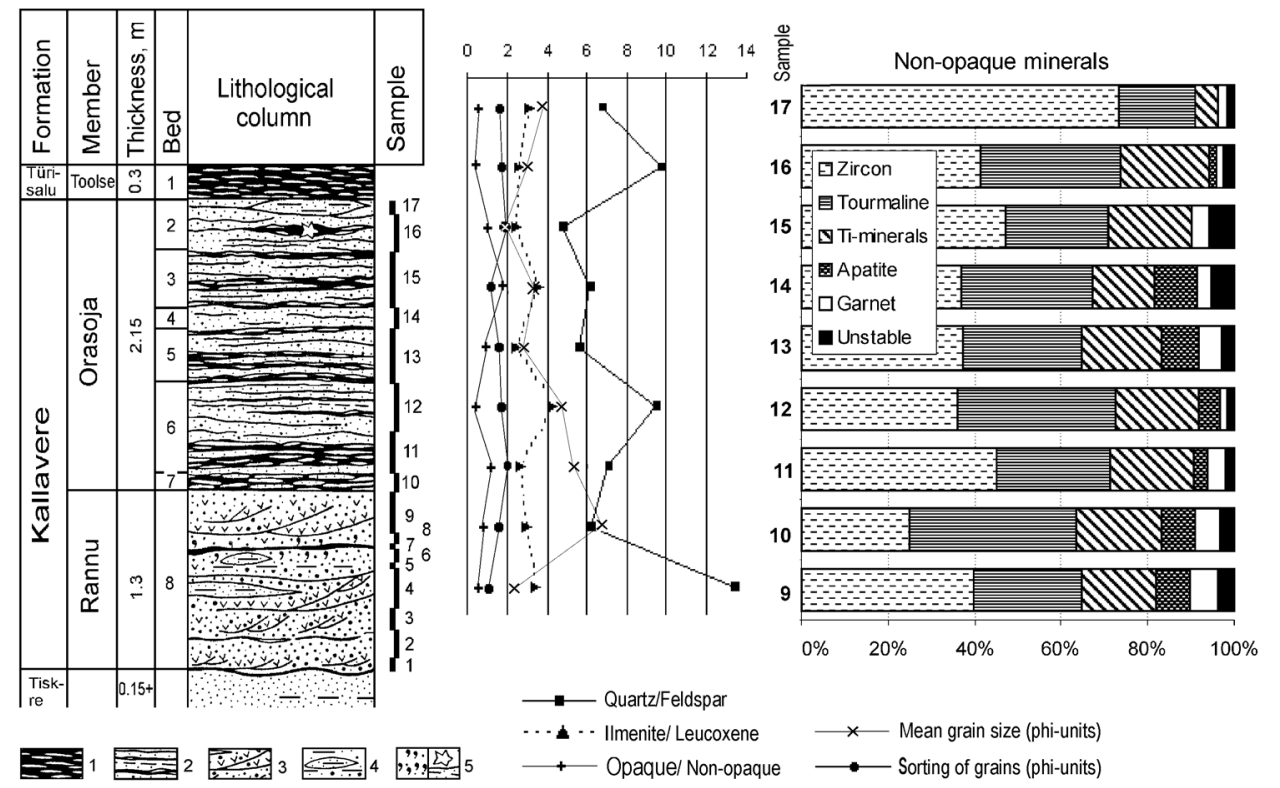

Fig. 3. Lithology and mineralogy of the Orasoja section. Lithological key: 1, black shale with sandy-silty lenses; 2, alternation of siltstone (or/and sandstone) and black shale; 3, cross-bedded sandstone with brachiopod bioclasts; 4, thin clay interbeds and lenses; 5, glauconite grains (left) and anthraconite concretion.

samples with the thickness of the sampling interval in parentheses are given. The same samples were used both for mineralogical and conodont studies. The entire outcrop is quite strongly impregnated with oxidized ferric minerals.

TÜRISALU FORMATION, Toolse Member (Lower Ordovician)

Bed 1: $0.30 \mathrm{~m}$. Dark-brown thin-bedded Dictyonema Shale containing laminae and lenses of quartzose silt and sand. Rust-coloured lenses and thin layers of very fine-grained authigenic masses of silica and small pyrite concretions as well occur in the shale. The top of the bed is strongly eroded, with rather deep vertical burrows filled with glauconitic sandstone from the overlying Leetse Formation. The lower boundary is transitional (see the lithology in the chapter below and Heinsalu et al. 1991a).

KALLAVERE FORMATION, Orasoja Member (Lower Ordovician)

Bed 2: $0.35-0.40 \mathrm{~m}$. Frequent alternation of light sandy quartzose siltstone and black shale, with siltstone prevailing. The shale laminae, mostly $1-2 \mathrm{~mm}$ thick, are unevenly distributed in the bed. A $3 \mathrm{~cm}$ thick shale layer at the bottom of the bed contains anthraconite concretions and very thin intercalations of siltstone. Samples: $17(0.10 \mathrm{~m}), 16(0.30 \mathrm{~m})$.

Bed 3: $0.40 \mathrm{~m}$. Silty very fine-grained sandstone alternating with relatively thick layers $(1-3 \mathrm{~cm})$ of black shale. The frequency and thickness of the shale 
interbeds decrease downwards. In the lowermost part of the bed $(0.15 \mathrm{~m})$ these interbeds become very thin $(\sim 1 \mathrm{~mm})$, and are often interrupted and wavy. Sample: $15(0.40 \mathrm{~m})$.

Bed 4: $0.15-0.25 \mathrm{~m}$. Sandy siltstone alternating with frequent laminae (1-2 mm thick) of black shale, mostly horizontal, in places wavy or interrupted. Sample: $14(0.15 \mathrm{~m})$.

Bed 5: 0.25-0.40 m. Alternation of fine-grained sandstone (layers $4-5 \mathrm{~cm}$ thick) and 5-6 cm thick layers of black shale. The shale includes small lenses or intercalations of the very fine-grained light sandstone and the latter, in turn, shale laminae. The lower part of the interval seems to be more shaly than the upper part where sandstone dominates. Sample: $13(0.40 \mathrm{~m})$.

Bed 6: $0.55-0.65 \mathrm{~m}$. Alternation of three interbeds of black shale $(6-9 \mathrm{~cm}$ thick) with very thin light sandy intercalations and three $9-12 \mathrm{~cm}$ thick interbeds of siltstone with frequent black shale laminae. Samples: $12(\sim 0.35 \mathrm{~m}), 11(\sim 0.30 \mathrm{~m})$.

Bed 7: 0.15-0.20 m. Laminated black shale with rare small lenses of light siltstone. The lower boundary of the shale is sharp, slightly wavy. Sample: $10(0.15 \mathrm{~m})$.

\section{KALLAVERE FORMATION, Rannu Member (Upper Cambrian-Lower Ordovician) \\ Bed 8: $1.20-1.30 \mathrm{~m}$. Medium- to fine-grained quartzose sandstone with} bioclastic admixture, weakly cemented, yellowish of different shades. The topmost part $(\sim 0.30 \mathrm{~m})$ of the sandstone is rust-coloured, but downwards only rusty spots occur. The sandstone is prevailingly cross-bedded, in places also horizontal or lenticular. The bedding is clearly visible due to the alternating layers of dark fragments of phosphatic brachiopods and light quartz grains. In the lower $0.20 \mathrm{~m}$ of the bed the bioclasts are concentrated in few small lenses. In the uppermost $0.40-0.60 \mathrm{~m}$ of the member two pelitic layers occur: $4 \mathrm{~cm}$ thick brown silty clay (sample 5) and $2-3 \mathrm{~cm}$ thick black shale (sample 7). Quartzose sandstone contains glauconite grains in $1-2 \mathrm{~mm}$ above and under this shale interbed. Samples: $9(0.30 \mathrm{~m}), 8(0.08 \mathrm{~m}), 7(0.03 \mathrm{~m}), 6(0.10 \mathrm{~m}), 5(0.04 \mathrm{~m}), 4(0.30 \mathrm{~m})$, $3(0.15 \mathrm{~m}), 2$ (0.20 m), 1 (0.10 m).

The lower boundary of the Rannu Member with the underlying very finegrained sandstones of the Tiskre Formation is horizontal, slightly uneven, and lithologically distinct. However, the junction of these two units is lithologically less abrupt than could be expected considering the extent of the hiatus between these beds corresponding to the middle and part of the upper Cambrian (Mens \& Pirrus 1987). According to conodont data, the Cambrian-Ordovician boundary is within the Rannu Member, in a 2-3 cm thick black shale interbed about $40 \mathrm{~cm}$ below the top (the first appearance of Cordylodus lindstromi and Iapetognathus sp. in sample 7).

TISKRE FORMATION (Lower Cambrian)

$0.15+\mathrm{m}$. Very fine-grained dirty-white quartzose sandstone, strongly cemented, with intercalations of greenish silty clay. 


\section{GENERAL CHARACTERISTICS OF THE STRATOTYPE AND DISCUSSION}

\section{Material and methods}

Samples for grain size, mineralogical, and palaeontological studies in the Orasoja section were taken from the same intervals ranging from 0.03 to $0.4 \mathrm{~m}$, allowing tight co-interpretation. For palaeontological studies all 17 samples were used, but the grain size and mineralogical analyses were carried out using 8 samples from the Orasoja Member and 1 sample from the Rannu Member. Eight grain size fractions $(>2.0,2.0-1.0,1.0-0.5,0.5-0.25,0.25-0.1,0.1-0.05,0.05-0.01$, and $<0.01 \mathrm{~mm}$ ) were separated by sieving, except the smallest fraction that was extracted by settling in water column. For mineralogical analysis the $0.1-0.05 \mathrm{~mm}$ fraction was used. Light and heavy fractions were separated using heavy liquid $\left(\mathrm{ROO}=2.89 \mathrm{~g} / \mathrm{cm}^{3}\right)$ and analysed by the immersion method.

\section{Lithology}

The stratotype section of the Orasoja Member is represented by the alternation of light quartzose siltstone and/or sandstone and laminated black shale (also termed Dictyonema Shale or dark kerogenous argillite). The sandstone is mostly very fine-grained (after the Udden-Wentworth scale), weakly cemented and commonly, except in some narrow intervals (see above), prevailing over black shale (thickness ratio about 2:1). The most characteristic lithological feature of the Orasoja Member is the frequent alternation of these two types of rocks - both a great number of subordinated black shale laminae in the silt- or sandstone and, vice versa, sandy-silty laminae and lenses in the thicker black shale interbeds. The shale laminae are mostly very thin: $1-2 \mathrm{~mm}$ or even less, but up to $6-9 \mathrm{~cm}$ thick interbeds embedding silty lenses also occur. The shale laminae and interbeds are mostly horizontal, partly lenticular, inclined or slightly wavy; sometimes they are arranged into groups. There is no clear regularity in the distribution of the shale interbeds and/or changes in their thickness in the Orasoja section. However, some rhythmical alternation of up to $0.40 \mathrm{~cm}$ thick shale-rich intervals and $0.15-0.30 \mathrm{~cm}$ thick more silty and sandy intervals can be noted. This cyclicity is only fairly distinct, but still two main cycles can be observed in the Orasoja Member. The lower cycle includes beds 4-7, the upper cycle beds 1-3. Changes in grain size and sorting of the clastic material of the sand- and siltstones corroborate this conclusion.

The described stratotype characterizes the Orasoja Member in its easternmost distribution area. Towards the west from the Orasoja outcrop the frequency of black shale interbeds decreases gradually, and west of Aseri the Orasoja Member is laterally replaced by the Katela Member, where only rare thin shale interbeds occur among fine- and very fine-grained quartzose sandstone.

The mean grain size of the siliciclastic material in the stratotype is $0.031 \mathrm{~mm}$ (5.0 $\Phi$-units). This corresponds to the coarse-medium siltstone (after the Udden- 
Wentworth scale) but in many cases the distribution curve of fractions is bimodal due to the frequent alternation of siltstone and black shale layers, both included in the composition of samples. No coarser grains than $0.5 \mathrm{~mm}$ and very few grains exceeding $0.25 \mathrm{~mm}$ are found in the member. The content of the $0.25-0.1 \mathrm{~mm}$ fraction varies from 2 to $53 \%$. The most frequent fraction of $0.1-0.05 \mathrm{~mm}$ ranges from 8 to $78 \%$ (mean 34\%). The content of the next frequent $0.05-0.01 \mathrm{~mm}$ fraction ranges from 6 to $26 \%$ (mean 16\%) and of the fraction finer than $0.01 \mathrm{~mm}$ from 6 to $64 \%$ (mean 33\%). The varying content of different fractions is caused by alternating sandy-silty and pelitic layers. In the Orasoja stratotype the mean sorting value is 1.7 ( $\Phi$-units), which corresponds to poor sorting processes (cf. Friedman et al. 1992). Only sample 14, the coarsest in the section, is moderately sorted, likely due to a longer period of sorting processes during a brief regression or due to the better sorted clastic material recycled to this bed. Therefore we consider that sample 14 (bed 4) marks the end of the lower cycle in the Orasoja Member. The grain size pattern described in the stratotype is characteristic of the member in its entire distribution area. The mean grain size of the member, however, is slightly coarser (fine sandstone to very coarse siltstone) and the sorting is better than in the Orasoja stratotype (Heinsalu \& Raudsep 2000). The grain size and sorting increase westwards and in the Saka-II section the Orasoja Member is composed of fine and very fine sandstone (Heinsalu et al. 1991a), similar to the Katela Member.

The changes in grain size in the sections presented by Heinsalu \& Raudsep (2000) allow us to distinguish between the changing sedimentation regime during the formation of the Orasoja sediments. In some cases continuous transgression was followed by the regressive phase, but sometimes there occurred two different transgressive cycles, as in the stratotype. In the lower cycle both the transgressive and the regressive phase are detected. According to the mean grain size data, the Orasoja Member is the most fine-grained unit of the Kallavere Formation and the sorting process was poor to moderate.

The analogous sedimentary structures, such as frequent alternation of black shale and sand- and siltstone layers characteristic of the Orasoja Member are continuing also in the overlying Toolse Member. Thus, the upper boundary of the Orasoja Member is transitional and was conventionally placed at the level, where black shale becomes predominant in the section (Heinsalu et al. 1991a). In contrast, the sedimentary environments and the corresponding rocks of the Orasoja Member and the underlying Rannu Member are clearly different. The boundary between these units is distinct and can be defined by grain size. The sandstone in the Rannu Member is considerably coarser (medium- to fine-grained) than in the Orasoja Member. Visually the Rannu Member seems to be even coarser because of the brachiopod fragments, which are partly coarser than siliciclastic grains. The proportion of phosphatic brachiopod fragments in the Rannu Member ranges from 15 to $30 \%$ of the whole rock, except for the lowest $0.2 \mathrm{~m}$ of the section, which contains only 7-8\% bioclasts. In the Orasoja Member the content of bioclasts is lower, usually below $1 \%$, and only the uppermost layer contains $8 \%$ brachiopod fragments. All the small shell fragments are more or less rounded, indicating recycling of the material. 


\section{Mineralogy}

The following chapter summarizes the results of the mineralogical analysis performed in the Orasoja stratotype and mainly concerning the rocks of the Orasoja Member (Table 1). Also some changes at the boundary between the Rannu and Orasoja members are discussed. Previous detailed mineralogical data about the Orasoja Member are available for comparison from the Saka-II section (Heinsalu et al. 1991a).

\section{Light minerals}

The quartz content in the light mineral fraction of the Orasoja Member (Fig. 3, samples 10-17) ranges from 69 to $90 \%$ (mean 84\%) and the K-feldspar content from 8.5 to $15 \%$ (mean $12.5 \%$ ). The K-feldspar grains have weathered cores (a distinctive feature for the recycled or diagenetically altered material) and well developed (0.01-0.02 mm thick) rims of authigenic feldspar. In the transition from the Rannu Member (sample 9) to the Orasoja Member (sample 10) the K-feldspar content increases rapidly and thus the ratio of quartz to feldspars (an indicator of maturity) decreases from 13 to 6 (Fig. 3). The relatively high content of feldspars compared to quartz is also established in black shales in North Estonia (Kleesment \& Kurvits 1987). This observation is in accordance with a general understanding that the content of feldspars compared to the quartz content is commonly higher in fine-grained sediments due to selective sorting and better preservation, but also because of the different origin of the sedimentary material. In the upper part of the Orasoja Member (sample 15), simultaneously with a decrease in the sorting and the quartz/feldspar ratio, the micas appear (up to 1.2\%) and the content of light authigenic minerals (calcite, rare grains of glauconite) increases to $16 \%$ of the light minerals. In the Saka-II section, where the black shale beds and laminae are scarcer than in Orasoja, the change in the quartz/feldspar ratio is not detected either in the transition from the Rannu Member to the Orasoja Member or in the Orasoja Member.

\section{Heavy minerals}

Main groups. In the stratotype the heavy fraction of the Orasoja Member (Fig. 3, samples 10-17) contains 3-32\% (mean 15\%) allothigenic opaque minerals, $2-41 \%$ (mean $17 \%$ ) allothigenic non-opaque minerals, $1-5 \%$ (mean $2.6 \%$ ) micas, and 36-94\% (mean 66\%) authigenic minerals. The Orasoja Member is relatively rich in opaque minerals, but this is more evident in the Saka-II section (Heinsalu et al. 1991 a) than in the stratotype. In the latter, the original sedimentological features of opaque minerals are masked by the processes of alteration. The nonopaque minerals like zircon and tourmaline are more stable than opaque minerals (ilmenite and leucoxene) and a high ratio of opaque to non-opaque minerals characterizes in many cases the content of new material in the rocks. In the stratotype non-opaque minerals dominate in the lower part of the member and in the very top, which reflects the essential amount of the recycled material derived from the underlying beds. The beginning of the upper cycle of the member 
Table 1. Mineralogical (fraction $0.1-0.05 \mathrm{~mm}$ ) and grain size data of the Orasoja (samples 10-17) and Rannu (sample 9) members in the stratotype section

\begin{tabular}{|c|c|c|c|c|c|c|c|c|c|c|c|c|}
\hline \multirow[t]{2}{*}{$\begin{array}{c}\text { Sample } \\
\text { No. }\end{array}$} & \multicolumn{2}{|c|}{ Grain size } & \multicolumn{4}{|c|}{ Light minerals } & \multicolumn{4}{|c|}{$\begin{array}{l}\text { Main mineral groups, } \\
\text { heavy fraction }\end{array}$} & \multicolumn{2}{|c|}{$\begin{array}{c}\text { Opaque } \\
\text { minerals, heavy } \\
\text { fraction }\end{array}$} \\
\hline & 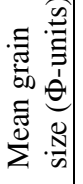 & 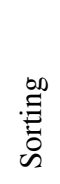 & $\begin{array}{l}\stackrel{N}{E} \\
\stackrel{\Xi}{0}\end{array}$ & 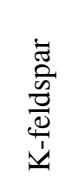 & $\stackrel{\tilde{J}}{\stackrel{0}{2}}$ & 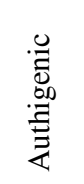 & $\begin{array}{l}\frac{\tilde{z}}{\tilde{\Xi}} \\
\text { Õ. }\end{array}$ & 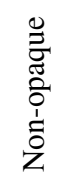 & $\stackrel{\tilde{J}}{\stackrel{0}{2}}$ & 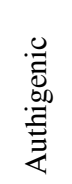 & 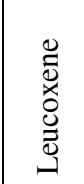 & 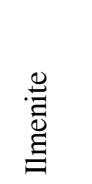 \\
\hline 17 & 6.2 & 1.6 & 84.8 & 12.5 & 1.8 & 0.9 & 2.4 & 2.6 & 1.1 & 93.5 & 24.6 & 75.4 \\
\hline 16 & 3.9 & 1.9 & 83.4 & 8.5 & 0.3 & 7.8 & 3.4 & 3.4 & 1.4 & 91.8 & 28.0 & 72.0 \\
\hline 15 & 4.8 & 1.9 & 69.4 & 14.6 & 0 & 16.0 & 4.4 & 1.8 & 1.2 & 92.6 & 28.7 & 71.3 \\
\hline 14 & 3.9 & 1.1 & 86.0 & 14.0 & 0 & 0 & 32.3 & 25.9 & 3.3 & 38.5 & 21.8 & 78.2 \\
\hline 13 & 5.4 & 1.8 & 84.5 & 15.1 & 0.4 & 0 & 3.4 & 4.6 & 2.7 & 89.3 & 28.4 & 71.6 \\
\hline 12 & 4.5 & 1.8 & 90.0 & 9.5 & 0 & 0.05 & 26.6 & 24.4 & 4.9 & 44.1 & 18.4 & 81.6 \\
\hline 11 & 5.2 & 2.1 & 87.7 & 12.3 & 0 & 0 & 25.5 & 31.5 & 2.6 & 40.4 & 27.3 & 72.7 \\
\hline 10 & 6.5 & 1.6 & 85.4 & 13.8 & 0.4 & 0.4 & 19.7 & 41.2 & 3.2 & 35.9 & 25.0 & 75.0 \\
\hline 9 & 2.4 & 1.0 & 88.3 & 6.6 & 0 & 5.1 & 24.2 & 36.2 & 1.2 & 38.4 & 22.8 & 77.2 \\
\hline
\end{tabular}

\begin{tabular}{|c|c|c|c|c|c|c|c|c|c|c|c|}
\hline \multirow{2}{*}{$\begin{array}{c}\text { Sample } \\
\text { No. }\end{array}$} & \multicolumn{7}{|c|}{ Non-opaque minerals, heavy fraction } & \multicolumn{4}{|c|}{ Ratios of minerals } \\
\hline & \begin{tabular}{l}
$\overline{0}$ \\
\multirow{0}{*}{} \\
\end{tabular} & 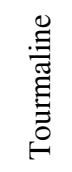 & 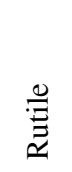 & 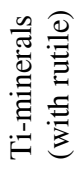 & $\begin{array}{l}\stackrel{\mathscr{0}}{\widetilde{0}} \\
\text { 完 }\end{array}$ & $\begin{array}{l}\vec{\Xi} \\
\stackrel{\Xi}{\Xi} \\
\end{array}$ & 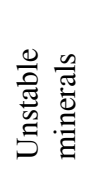 & 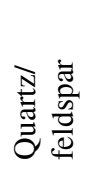 & 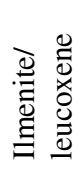 & 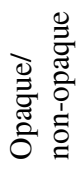 & 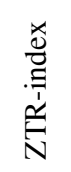 \\
\hline 17 & 39.9 & 24.8 & 12.7 & 17.2 & 7.8 & 6.5 & 3.8 & 6.8 & 3.1 & 0.7 & 77.4 \\
\hline 16 & 24.8 & 38.6 & 16.1 & 19.6 & 7.8 & 6.1 & 3.1 & 9.8 & 2.6 & 0.39 & 79.5 \\
\hline 15 & 45.2 & 26.0 & 9.4 & 19.5 & 3.1 & 4.2 & 2.0 & 4.8 & 2.5 & 1.2 & 80.6 \\
\hline 14 & 36.0 & 36.7 & 11.0 & 19.3 & 4.7 & 1.7 & 1.6 & 6.1 & 3.6 & 1.5 & 83.7 \\
\hline 13 & 37.1 & 27.5 & 10.7 & 18.6 & 8.4 & 5.6 & 2.8 & 5.6 & 2.5 & 0.9 & 75.3 \\
\hline 12 & 36.9 & 30.3 & 8.8 & 14.5 & 9.8 & 3.2 & 5.3 & 9.5 & 4.4 & 0.6 & 76.0 \\
\hline 11 & 47.3 & 23.8 & 13.1 & 19.2 & 0 & 3.8 & 5.9 & 7.1 & 2.7 & 1.2 & 84.2 \\
\hline 10 & 41.4 & 32.2 & 14.4 & 20.5 & 1.6 & 2.0 & 2.3 & 6.2 & 3.0 & 1.0 & 88.0 \\
\hline 9 & 73.5 & 17.4 & 3.3 & 5.6 & 0 & 1.9 & 1.6 & 13.4 & 3.4 & 0.67 & 94.2 \\
\hline
\end{tabular}

is characterized by abundance of opaque minerals (sample 15). This mineralogical change is not distinctive, but the increase in the relative abundance of opaque minerals starts already in sample 14. Thus, this interval reflects a continuous sedimentary process with a decreasing role of the recycled and increasing input of the new material. The content of bioclasts (fragments of brachiopods and 
conodonts) is also essential in the heavy fraction. The concentration of conodont fragments in fine fractions of the Orasoja sediments is notable.

Authigenic minerals. The whole outcrop is rust-coloured, showing the influence of the weathering processes on the mineral association. Similar to other minerals, the distribution of authigenic minerals is different in the lower and upper parts of the member. The lower part is rich in pyrite, partly oxidized to Fe-oxides and -hydroxides. Intensive formation of anatase is observed. The upper part of the section contains secondary phosphatic minerals (more often the lower part) and also rare carbonate grains. The content of Fe-oxides and -hydroxides is higher in the intervals showing frequent alternation of siltstone and black shale layers. The Orasoja Member in the Saka-II section is also rich in pyrite, which is partly oxidized. Rare grains of glauconite, but no anatase were detected in the samples.

Allothigenic opaque minerals. The main minerals among the allothigenic opaque minerals in the stratotype are ilmenite and leucoxene. Some rare magnetite grains occur in shaly samples. The occurrence of magnetite is common for the black shale formation in Estonia (Kleesment \& Kurvits 1987). In the stratotype the ilmenite/leucoxene ratio is 2.5-4.4, which is lower than in other members of the Kallavere Formation. Ilmenite, however, is strongly weathered in the stratotype. Many ilmenite grains are covered with yellow-white spots and coatings (leucoxene) and little crystals of anatase. During the weathering or diagenesis in clastic sediments, ilmenite loses iron up to the formation of pure $\mathrm{TiO}_{2}$ (leucoxene, anatase, rutile) (Morad \& Aldahan 1986). If the mineral material is altered in the described way, the anatase crystals disappear during the recycling and only rounded leucoxene is left from the altered material. The ilmenite/leucoxene ratio decreases, which is interpreted as an indication of recycled material. For the Katela Member in the Nõmmeveski section (Kleesment \& Kurvits 1987), consisting of more sorted sandstones and only very few shale layers, the ilmenite/leucoxene ratio is over 10 . This could be explained by the decreasing frequency of shale layers contributing to the diagenetic alteration process of $\mathrm{Fe}-\mathrm{Ti}$ minerals. Thus, the original sedimentary processes and input of the ilmenite-rich new material in the Orasoja Member are masked by the in situ alteration processes and are not very clearly observable.

Allothigenic non-opaque minerals. The main minerals of this group and their average values for the eight samples (Nos. 10-17) from the Orasoja Member are zircon $(39 \%)$, tourmaline $(30 \%)$, and rutile $(12 \%)$. The zircon-tourmaline-rutile (ZTR) index values (75-88\%) are characteristic of mature sediment (Mange \& Maurer 1992), but in the other members of the Kallavere Formation this value is even higher (over 90\%). The ZTR-index has its maximum value in sample 10 from the lowermost part of the member, decreasing upwards, and starting to increase from sample 14. In sample 9 from the Rannu Member the ZTR-index is 94\%, increasing continuously in the transition to the Orasoja Member. The content of weathered titanium minerals is highest at the boundary of the two distinguished cycles.

The contents of apatite (5.4\%) and garnet (4.1\%) are higher in the Orasoja Member than in the other members of the Kallavere Formation (Heinsalu et al. 
1991a). The content of other unstable minerals is also relatively high (5.3\%). Opposite to the ZTR-index, the content of unstable minerals increases in the stratotype upwards in both cycles. For comparison, in the Saka-II section the upper part (starting from sample 2, the beginning of the $C$. angulatus Zone) of the Orasoja Member also shows higher contents of apatite and garnet. In general, the mineral composition of the Orasoja Member does not differ much from that of the other members of the Kallavere Formation. Yet, in the association of allothigenic non-opaque heavy minerals and the content of garnet the Orasoja Member is closer to the Rannu Member than to the macrolithologically more similar Katela Member. Therefore we can consider that main amount of the recycled material in the Orasoja Member was derived from the sediments of the Rannu Member. Heinsalu et al. (1994) have suggested that during C. lindstromi (and, possibly, C. angulatus) time, unsorted sandy material rich in phosphatic brachiopod fragments formed relatively high sand bars in a shallow sea, separating small basins from the active water and allowing formation of thin alternating sandy-silty and black shale beds of the Orasoja Member.

Some mineralogical data reported above are surprisingly well correlated with the conodont biozonation and graptolite finds. The increase in the ratio of opaque (ilmenite, magnetite) minerals to non-opaque minerals and in the ratio of quartz to feldspars in sample 15 coincides with the appearance of abundant specimens of Cordylodus angulatus. In the stratotype the changes in the grain size and sorting at this level are vaguely distinguished, but in the other sections quite well established (Heinsalu \& Raudsep 2000). Some changes in the mineral content (ZTR-index, unstable minerals, composition of bioclasts) start in sample 14 (Fig. 3), where the first appearance of the graptolite $R$. $f$. cf. multithecata is described. In the stratotype, a large variety of minerals and more angular shape of clastic grains, as compared to usual features of minerals known from the earlier rocks of the Kallavere Formation, support the consideration that influx of new material contributed to the formation of the upper part of the Orasoja Member.

A detailed mineralogical analysis of the Rannu Member was not performed in the Orasoja stratotype, but the lower boundary of the Cordylodus lindstromi conodont Zone in the adjacent Saka-II section (Heinsalu et al. 1991a, 1991b) marks the beginning of finer sedimentary material and a higher quartz/feldspars ratio. However, these features of mineral composition (high ilmenite/leucoxene ratio, increased garnet content, unstable non-opaque minerals), distinguishing the mineral material in the Kallavere Formation, appear more clearly in the C. angulatus Zone.

\section{CONODONTS}

Conodonts of the Kallavere Formation in the Orasoja outcrop were studied based on the collection obtained from 17 samples (Fig. 4). All the samples yielded conodonts although the number of elements and preservation were different. The 
Conodont Alteration Index (CAI) is 1-1.5, but in samples 1-6 conodonts are light reddish-brown. The current low value of the CAI indicates that the studied rocks are well preserved, not strongly heated, but the coloration of conodonts from the first six samples refers to some environmental (chemical ?) influence. The distribution of the species identified is shown in Fig. 4.

The Cordylodus proavus, $C$. lindstromi, and $C$. angulatus conodont zones were identified in the Orasoja section. The index species Cordylodus proavus Müller is quite numerous and represented by different morphological types in the three lower samples. Besides typical specimens (Fig. 5, 1-4), some with secondary tips, there occur single specimens similar to $C$. caboti Bagnoli, Barnes \& Stevens (Fig. 5, 7) and C. prion Lindström sensu Nicoll 1991 (Fig. 5, 5). In sample 2, a specimen similar to Cordylodus sp. nov. A Nicoll 1990 (Fig. 5, 6) is found. In the East Baltic similar specimens were earlier identified as $C$. intermedius Furnish. Now it is reasonable to agree with Nicoll's interpretation that the holotype of the latter species belongs to the apparatus of C. angulatus Pander (Nicoll 1990). Nicoll noted also that not all of the material previously assigned to C. intermedius could be reassigned to $C$. angulatus. This is the case with the East Baltic material which we believe to belong to Cordylodus sp. nov. A Nicoll 1990, whose stratigraphical range is between those of C. proavus and C. angulatus (Nicoll 1990). Single specimens of Westergaardodina in sample 4 and Proconodontus (Fig. 5, 8) in samples 7 and 8 were also found.
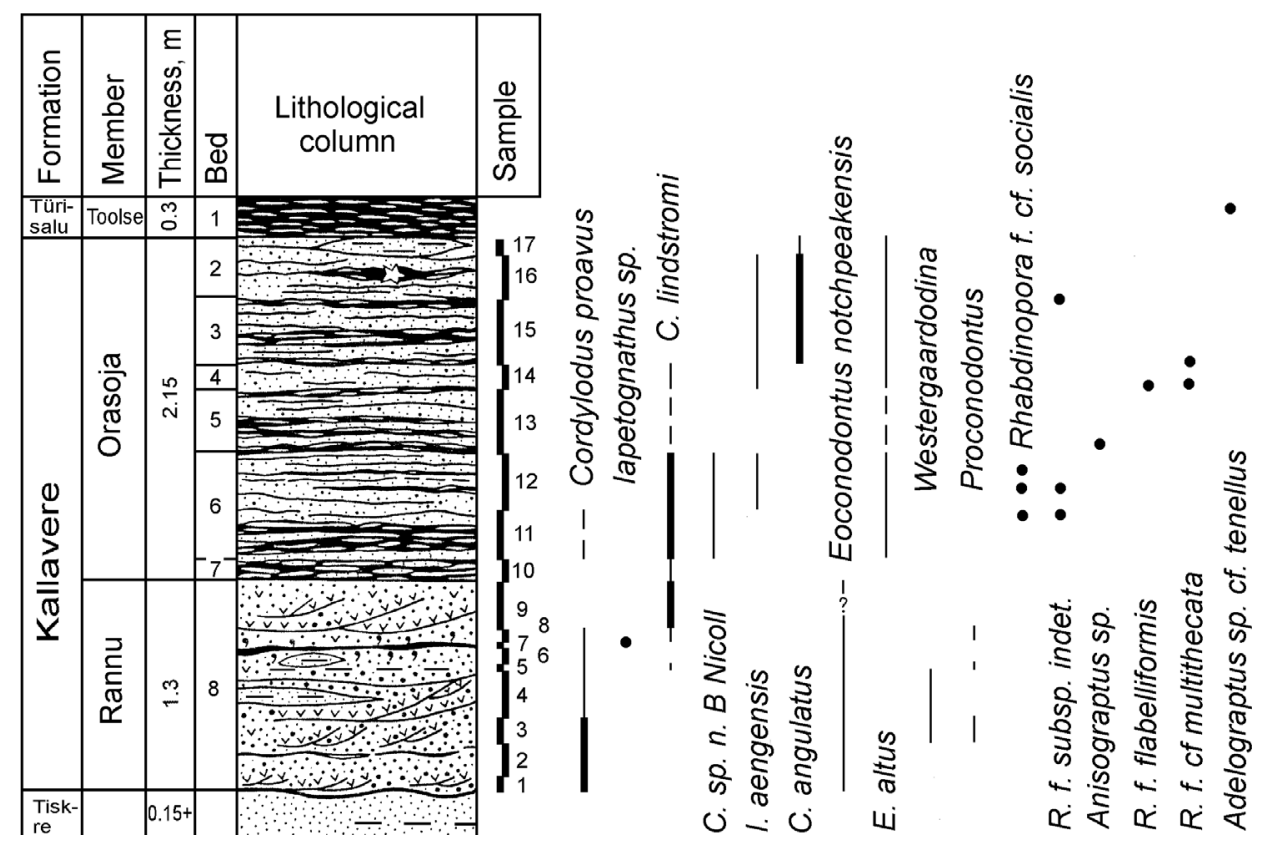

Fig. 4. Distribution of conodonts and graptolites in the Orasoja section. For key see Fig. 3. 


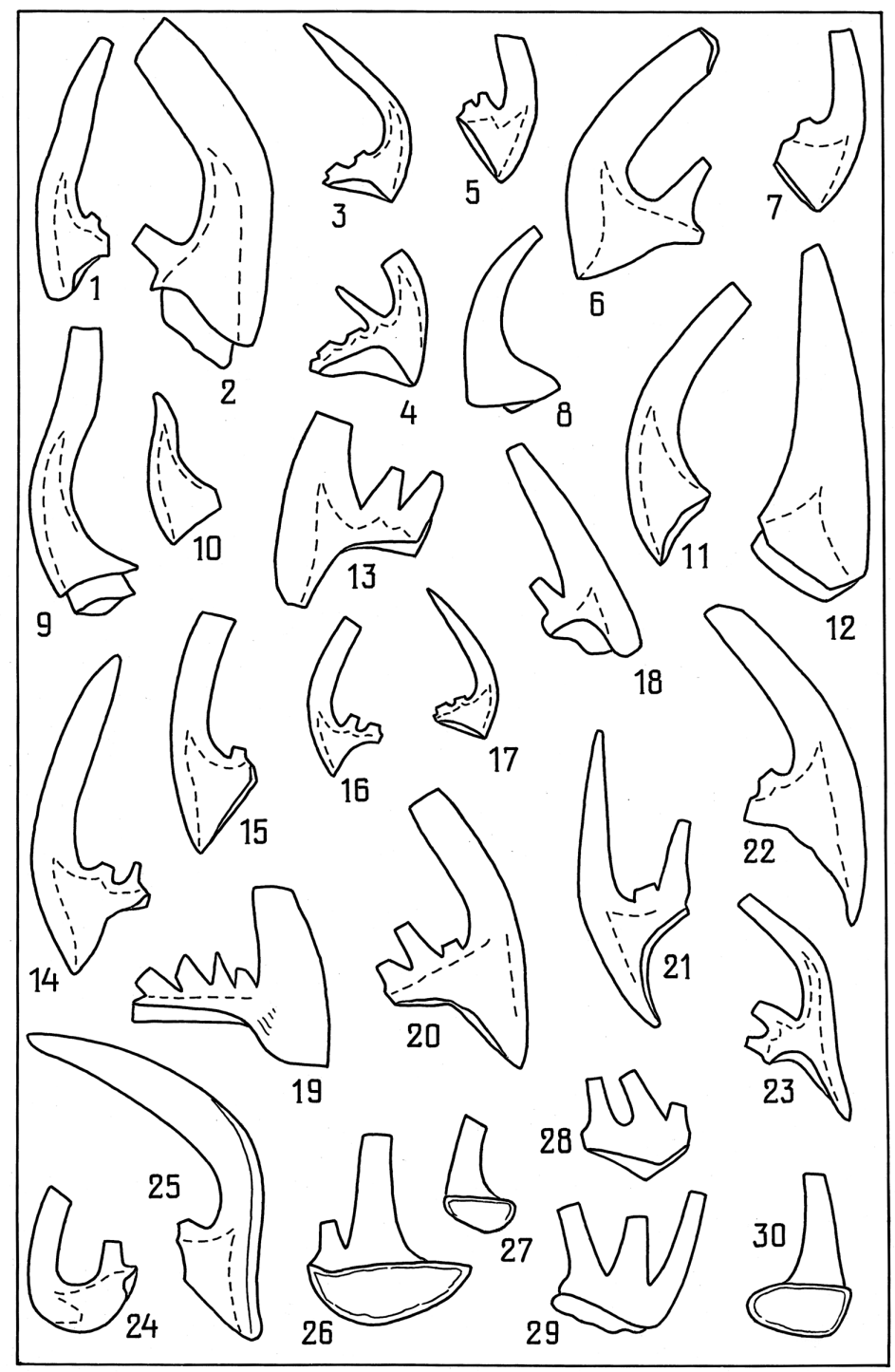

Fig. 5. Conodonts from the Orasoja section. 1-4. Cordylodus proavus Müller. S and P elements, GIT 390-1 to 390-4; 1, 2 - sample 2, 3 - sample 3, 4 - sample 8. 5. Cordylodus ? prion Lindström. ?P element, GIT 390-5, sample 3. 6. Cordylodus sp. nov. A Nicoll 1990. P element GIT 390-6, sample 2. 7. Cordylodus ? caboti Bagnoli, Barnes \& Stevens. S element, GIT 390-7, sample 2. 8. Proconodontus sp. GIT 390-8, sample 8. 9, 10. Eoconodontus notchpeakensis (Miller). Rounded and compressed elements, GIT 390-9 and 390-10; 9 - sample 1, 10 - sample 3. 11,12. Eoconodontus altus (Viira). Rounded and compressed elements, GIT 390-11 and 390-12, sample 15. 13-20. Cordylodus lindstromi Druce \& Jones. 13, 18, 19 - M elements, GIT 390-13, 390-14, and 390-15; 14-17, 20 - S elements, GIT 390-16 to 390-20; $13,14,18$ - sample $11,15,19,20$ - sample 12,16 - sample 9 , 17 - sample 8. 21-23. Cordylodus sp. nov. B Nicoll 1991. S elements, GIT 390-21, 390-22, and 390-23; 21, 22 - sample 11, 23 - sample 12. 24, 25. Cordylodus angulatus Pander. P and S elements, GIT 390-23 and 390-25, sample 15. 26-30. Iapetognathus aengensis (Lindström). S elements, GIT 390-26 to 390-30; 26, 29, 30 - sample 16, 27, 28 - sample 15 . All specimens $\times 90$. 
C. lindstromi Druce \& Jones makes its first appearance in sample 7 and this level may be regarded as the lower boundary of the $C$. lindstromi Zone. This level coincides with a lithological boundary which is marked by a $2-3 \mathrm{~cm}$ thick layer of the black shale and numerous fragments of lingulate brachiopods. The specimens usually regarded as typical C. lindstromi in the East Baltic (Viira et al. 1987; Mens et al. 1989; Heinsalu et al. 1991b) are illustrated in Fig. 5 (13-20). In the apparatus construction by Nicoll (1990), these specimens correspond to the $\mathrm{Sd}$ element. The holotype of $C$. lindstromi is the M element with secondary tips. Similar M elements are represented also in sample 11 of the Orasoja section (Fig. 5, 13, 18). The samples with the most abundant specimens of $C$. lindstromi are 11 and 12. In these two samples some specimens with the extended anterobasal end like anticusp are identified as Cordylodus sp. nov. B Nicoll 1991 (Fig. 5, 21-23). This new form was found from the lower part of the Corrie Member of the Ninmaroo Formation at Black Mountain, Australia, with the stratigraphic range within the C. lindstromi Zone (Nicoll 1991). Eoconodontus notchpeakensis Miller (Fig. 5, 9, 10) in lower samples is succeeded upwards by E. altus Viira (Fig. 5, 11, 12) beginning with sample 11.

The Orasoja section is remarkable for the occurrence of Iapetognathus elements. Twelve specimens were found in four samples $(12,14-16)$, representing mainly S elements (Nicoll et al. 1999). Although most of the specimens are broken, it was possible to identify them (Fig. 5, 26-30) as Iapetognathus aengensis (Lindström). A small broken fragment of Iapetognathus sp. was found in sample 7.

In the global stratotype section (Green Point, western Newfoundland) and elsewhere, I. aengensis appears within the range but slightly above the base of the I. fluctivagus Zone, which marks the lower boundary of the Ordovician System just below the first appearance of planktic graptolites (Nicoll et al. 1999; Cooper et al. 2001). Therefore the first appearance of I. aengensis or Iapetognathus sp. in the Orasoja section can be used for tracing the Cambrian-Ordovician boundary. Here we consider the appearance of the genus Iapetognathus as the most important criterion and accordingly suggest to draw the Cambrian-Ordovician boundary in the Orasoja section in the upper part of the Rannu Member at the level, where Iapetognathus sp. appears together with the typical C. lindstromi (sample 7). Representatives of Iapetognathus are too rare in Estonia for defining a separate zone, but their occurrences in the $C$. lindstromi Zone provide an additional criterion for the correlation with the I. fluctivagus Zone in the global boundary stratotype.

C. angulatus makes its first appearance in samples 15 and 16, where it occurs in large numbers (Fig. 5, 24, 25). The C. angulatus Zone has been usually very clearly identifiable, but having the above discussion about relations of $C$. intermedius and $C$. angulatus in mind, the estimation of the range of the zone can be complicated in some sections. A revision of these two species is a task for the nearest future.

In the context of the above discussion, we would like to comment on some conodonts identified in the Tõnismägi section of northwestern Estonia. Cooccurrences of conodonts and graptolites in the Cambrian-Ordovician boundary 
beds of this section have been described earlier (Kaljo et al. 1988). Recent publications on Cordylodus and Iapetognathus apparatuses (Nicoll 1990, 1991; Nicoll et al. 1999) allow us to reinterpret some of the Tõnismägi conodonts. Based on the apparatus model of C. lindstromi by Nicoll 1990, we reassign several S elements of $C$. proavus with secondary tips (Kaljo et al. 1988, figs. 4k, 5k) as early specimens of $C$. lindstromi in samples 2 and 3 of Kaljo et al. (1988). In the Tõnismägi section, typical $C$. lindstromi occurs in sample 6 and above. $C$. intermedius and $C$. aff. drucei Miller from sample 7 should belong to Cordylodus sp. nov. A Nicoll 1990 and C. intermedius in sample 9 to C. angulatus. Iapetognathus is represented by the species I. aengensis (samples 3, 9, 10) as we accept the suggestion by Nicoll et al. (1999) to regard I. praeaengensis synonymous with I. aengensis.

Proceeding from this revision, the C. proavus, C. lindstromi, and C. angulatus conodont zones can be identified in the Tõnismägi section. We refrain from using the term C. lindstromi s.l. Zone (Cooper 1999), because the so-called earlier forms of $C$. lindstromi, including C. prolindstromi, are taxonomically too uncertain for any exact biostratigraphical work.

\section{GRAPTOLITES}

Dendroid graptolites collected from the Orasoja stratotype section are mostly rather fragmentary, but few better preserved specimens allow species-level identification. A list of species identified in this small collection of dendroids and their distribution through the section were published by Kaljo \& Kivimägi (1976) and together with conodont data by Kaljo \& Viira (1989). Below we present results of a revision of the earlier data, which was performed considering the main new literature about the Tremadocian graptolites, especially the paper by Cooper et al. (1998). The anisograptid nomenclature suggested by these authors is accepted here, with some comments added.

Figure 4 demonstrates taxonomic names and distribution through the section. Graptolites were identified in ten samples, nine of which belong to the Orasoja Member and one to the lowermost beds of the overlying Dictyonema Shale of the Türisalu Formation. The latter sample contains a fragmentary anisograptid, but not a Rhabdinopora. The absence of Rhabdinopora is in accord with an earlier conclusion (Kaljo \& Kivimägi 1970, 1976) that the Dictyonema Shale is a diachronous unit which reaches in Northeast Estonia the Upper Tremadocian Clonograptus sarmentosus Zone and therefore contains no rhabdinoporas that occur at lower levels in western localities.

The graptolite-bearing samples from the Orasoja Member represent different black shale intercalations embedded in very fine-grained sandstone (Fig. 6, 4). The black shale-sandstone interface might be sharp or transitional, referring to a changeable sedimentary process, fairly often going on without any serious interruptions. The following three groups of samples can be distinguished: 
1. The lowermost three samples from bed 6 (Fig. 4) contain many specimens of Rhabdinopora flabelliformis cf. socialis (Salter) (cf. is conventional due to fragmentary preservation, but no doubt, the characteristic features of the subspecies are well seen, Fig. 6, 1). Earlier (op. cit.) we have identified here also $R$. f. cf. desmograptoides (Hahn), but now we refrain from that determination (R. flabelliformis subsp. indet. is used in Fig. 4) and agree with Cooper et al. (1998) that it is a doubtful subspecies, which might be distinguished only in specific cases of preservation. In contrast, $R$. $f$. socialis is usually clearly identifiable thanks to closely spaced slightly undulating stipes and irregular but fine dissepiments. From 13 measured specimens, 11 show $12-13$ stipes in $10 \mathrm{~mm}$ and only two have 11. The number of visible dissepiments depends more on preservation; in our samples we counted $12-14$ in $10 \mathrm{~mm}$, but in some specimens only $8-10$. The width of the stipes varies from 0.3 to $0.45 \mathrm{~mm}$. Thecae number 14-16 in $10 \mathrm{~mm}$. All these characters fit well into the R. f. socialis concept (Bulman 1954; Cooper et al. 1998). This subspecies marks the first appearance level of the graptolites of the Rhabdinopora flabelliformis group in Estonia, but no early representatives of the group (R.f. parabola (Bulman)) have been found here. In this sense the early Tremadocian graptolite succession in Orasoja is incomplete, but in terms of the international graptolite zonation by Cooper (1999), the $R$. f. socialis interval may occupy the upper part of the R.f. parabola Zone and/or the lower part of the Anisograptus matanensis Zone.

2. A sample just above the previous samples, in the bottom of bed 5, shows an interesting assemblage consisting of a mass of mainly small fragments of Anisograptidae gen. et sp. indet. Revising the collection we did not find the longer fragment, which was earlier reported as Clonograptus sp. (Kaljo \& Kivimägi 1976; Kaljo \& Viira 1989) and therefore the generic content of the sample should remain open. Among many small pieces of stipes there occur rather often juvenile specimens, but obvious rhabdinoporas seem to be missing at this level. The latter statement cannot be considered as proved, vice versa, we see here a sorting effect of sea water dynamics, which might have created this specific association. Kaljo \& Kivimägi (1976) correlated this level with the earlier Anisograptus horizon in the Oslo Area (Bulman 1954) and the Clonograptus tenellus Zone in Scania (Tjernvik 1958), which both remain below the $R$. f. anglica Zone. The earlier conclusion seems to be true even if our data are less conclusive. It may also be a brief implication of the A. matanensis Zone association established in Canada and elsewhere (Cooper 1999).

3. The uppermost three graptolite samples from the Orasoja Member (Fig. 4, beds 3 and 4) contain R. flabelliformis flabelliformis Eichwald and R.f. multithecata (Bulman). This community is slightly impoverished: R. f. anglica (Bulman), a quite typical species of the upper part of the Lower Tremadocian of Estonia, is missing. If $R$. f. flabelliformis (Fig. 6, 2) is a long-ranging subspecies (the first specimens occur within the $R$. $f$. socialis interval), then $R$. $f$. multithecata is very characteristic of this part of the sequence (Fig. 6, 3; Orasoja specimens are too fragmentary for illustration). We agree with Cooper et al. (1998) that the last subspecies is in many aspects, including wide spacing of stipes (6 in $10 \mathrm{~mm}$ ), 

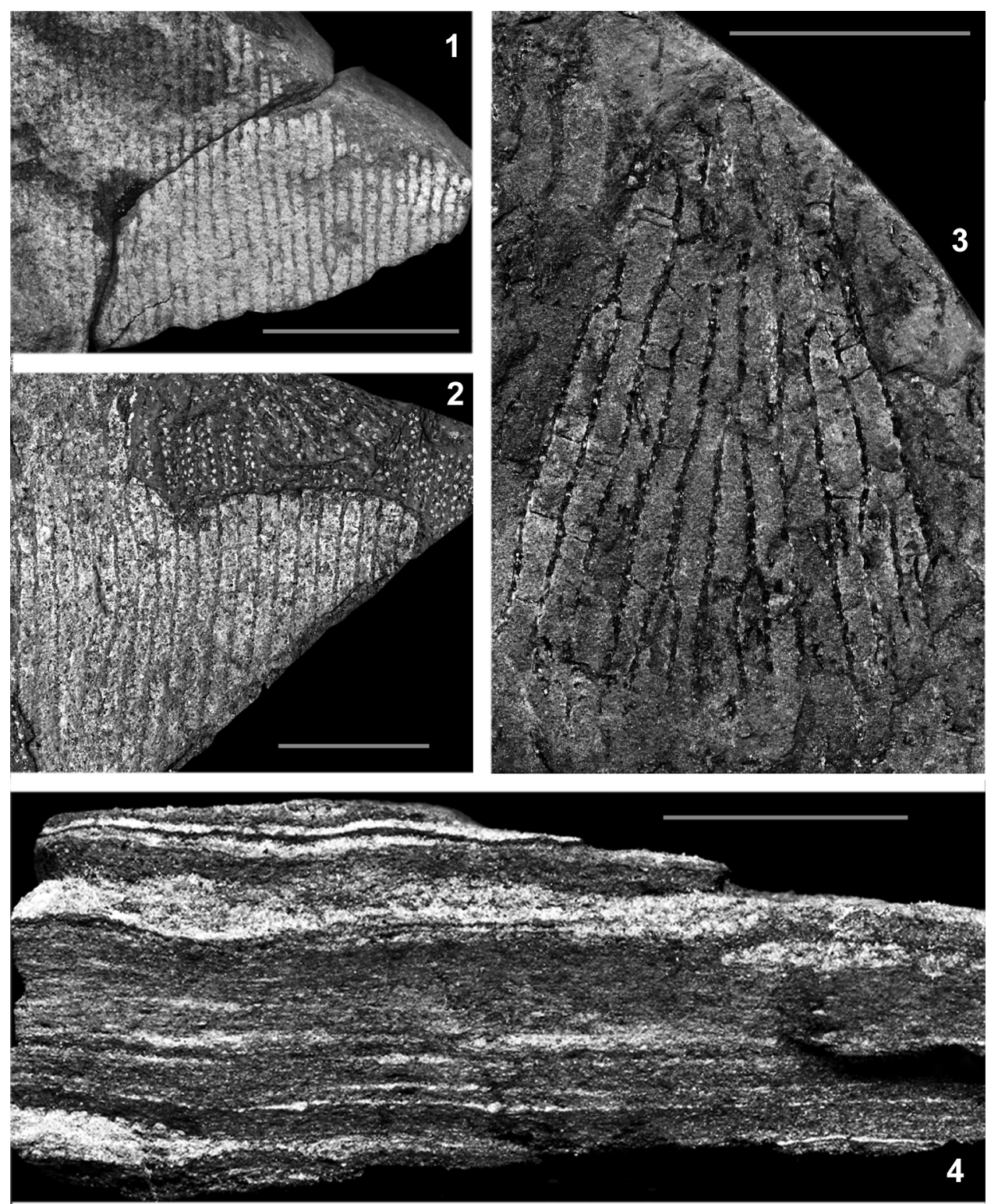

Fig. 6. Graptolites and a lithological example from the Orasoja section. 1. Rhabdinopora flabelliformis cf. socialis (Salter), GIT 390-31, sample V-2057 from bed 6. 2. Rhabdinoporaf. flabelliformis Eichwald, GIT 390-32, sample V-2055 from bed 4. 3. Rhabdinopora flabelliformis cf. multithecata (Bulman), GIT 390-33, sample D-188-9 (gr) from drill core D-188, depth 76.8 m, coll. H. Heinsalu. 4. A typical piece of the black shale layer with light siltstone lenses and thin intercalations. Sample V-2057 from bed 6 . All scale bars $1 \mathrm{~cm}$. 
similar to R. f. anglica, yet it clearly differs from the latter in very closely spaced thecae (in three Orasoja specimens $18-20$ in $10 \mathrm{~mm}$ ). Certain complications arise because we do not possess any complete rhabdosomes of $R$. f. multithecata and thus its general shape is unknown. Also, its apertural spines are very rarely well preserved. Nevertheless, real difficulties of identification appear when some anglica-multithecata transitions occur in the section, such as noted in several drill cores west of Tallinn (Kaljo \& Kivimägi 1970).

In Northwest Estonia R. f. multithecata occurs often together with R. f. anglica in the upper part of the Dictyonema Shale (Türisalu Formation, Fig. 2), thus marking the R.f. anglica Zone of the topmost Lower Tremadocian (Kaljo \& Kivimägi 1970, 1976). In the Orasoja section R. f. multithecata occurs below the beginning of the $C$. angulatus conodont Zone (Fig. 4), which seems extraordinary considering some Estonian data (Kaljo \&Viira 1989) or global generalization by Cooper (1999). Our old data need to be revised, but are still in line with the conclusion of the latter author that the base of the C. angulatus Zone lies normally in the lower part of the A. matanensis Zone.

\section{CONCLUSIONS}

The Orasoja Member is represented by specific alternation of light quartzose siltstone, partly sandstone, and black shales. The shale interbeds are mostly very thin and contain, in turn, even thinner silty-sandy lenses. The proportion of shale is cyclically variable, but siltstone is mainly prevailing. In mineral composition quartz is dominating, $\mathrm{K}$-feldspar forming a minor component of the rock. The low ratio of quartz to feldspars is characteristic of a quite new sedimentary material. Main changes in the mineral and grain size composition occur at the boundary of the Rannu and Orasoja members, but also higher at the appearance of C. angulatus (samples 14 and 15), where two cycles can be distinguished considering the changes in the ratios of opaque to non-opaque minerals and quartz to feldspar.

The Cordylodus proavus, C. lindstromi, and C. angulatus conodont zones are established in the Kallavere Formation of the Orasoja section. Considering the new interpretation of $C$. intermedius, the succession of conodont zones is here revised and compared with earlier publications (Kaljo et al. 1986). The first appearance of Iapetognathus sp. in the upper part of the Rannu Member (sample 7) is used together with $C$. lindstromi to determine the Cambrian-Ordovician boundary.

Graptolite information is in good accord with conodont data. The first representatives of the Rhabdinopora flabelliformis group appear in the Orasoja section within the $C$. lindstromi Zone $0.9 \mathrm{~m}$ above the lower boundary. $R$. $f$. socialis occurring in this section may occupy, in terms of international graptolite zonation by Cooper (1999), the upper part of the $R$. f. parabola Zone and, together with the Anisograptus sp. level, the lower part of the Anisograptus matanensis Zone. $R$. f. multithecata dates the beginning of the $R$. f. anglica Zone slightly below the C. angulatus conodont Zone. 


\section{ACKNOWLEDGEMENTS}

This study was partly supported by the Estonian Science Foundation (grants Nos. 3498, 4674, and 5275) and by target financed project No. 0331760s01. The technical help of G. Baranov, O. Hints, and K. Ronk is gratefully acknowledged. The reviewers K. Mens and I. Puura in particular are thanked for constructive criticism and many linguistic improvements.

\section{REFERENCES}

Bulman, O. M. B. 1954. The graptolite fauna of the Dictyonema Shales of the Oslo Region. Norsk Geol. Tidssk., 33, 1-40.

Cooper, R. A. 1999. Ecostratigraphy, zonation and global correlation of earliest Ordovician planktic graptolites. Lethaia, 32, 1-16.

Cooper, R. A., Maletz, J., Wang Haifeng \& Erdtmann, B.-D. 1998. Taxonomy and evolution of earliest Ordovician graptoloids. Norsk Geol. Tidssk., 78, 3-32.

Cooper, R., Nowlan, G. S. \& Williams, S. H. 2001. Global stratotype section and point for the base of the Ordovician System. Episodes, 24, 19-28.

Friedman, G. M., Sanders, J. E. \& Kopaska-Merkel, D. C. 1992. Principles of Sedimentary Deposits. Macmillan Publishing Company, New York.

Heinsalu, H. 1987. Lithostratigraphical subdivision of Tremadoc deposits of North Estonia. Proc. Acad. Sci. ESSR. Geol., 36, 66-78 (in Russian).

Heinsalu, H. \& Raudsep, R. 2000. Lithology of the Kallavere Formation on the North-Estonian Klint (Part II - Kunda-Narva area). Bull. Geol. Surv. Estonia, 9/1, 24-31.

Heinsalu, H., Kurvits, T. \& Oja, T. 1991a. Lithologic-mineralogical characteristics of the stratotypical section of the Rannu Member $\left(\mathrm{C}_{3}-\mathrm{O}_{1} k l \mathrm{R}\right)$ at Saka II, North-East Estonia. Proc. Estonian Acad. Sci. Geol., 40, 1-7 (in Russian).

Heinsalu, H., Viira, V. \& Paalits, I. 1991b. Cambrian-Ordovician boundary beds in the Saka II section, North-East Estonia. Proc. Estonian Acad. Sci. Geol., 40, 8-15 (in Russian).

Heinsalu, H., Viira, V. \& Raudsep, R. 1994. Environmental conditions of shelly phosphorite accumulation in the Rakvere phosphorite region, northern Estonia. Proc. Estonian Acad. Sci. Geol., 43, 109-121.

Kaljo, D. \& Kivimägi, E. 1970. On the distribution of graptolites in the Dictyonema Shale of Estonia and on the uncontemporaneity of its different facies. ENSV TA Toim. Keemia Geol., 19, 334-341 (in Russian).

Kaljo, D. \& Kivimägi, E. 1976. Zonal stratigraphy of the Estonian Tremadocian. In Graptolites and Stratigraphy (Kaljo, D. \& Koren, T. N., eds.), pp. 56-63. Institute of Geology, Estonian Academy of Sciences, Tallinn (in Russian).

Kaljo, D. \& Viira, V. 1989. Co-occurrences of conodonts and graptolites in the Estonian early Tremadoc. Proc. Estonian Acad. Sci. Geol., 38, 97-100.

Kaljo, D., Borovko, N., Heinsalu, H., Khazanovich, K., Mens, K., Popov, L., Sergeyeva, S., Sobolevskaya, R. \& Viira, V. 1986. The Cambrian-Ordovician Boundary in the Baltic-Ladoga clint area (North Estonia and Leningrad Region, USSR). Proc. Estonian Acad. Sci. Geol., 35, 97-108.

Kaljo, D., Heinsalu, H., Mens, K., Puura, I. \& Viira, V. 1988. Cambrian-Ordovician Boundary beds at Tõnismägi, Tallinn, North Estonia. Geol. Mag., 125, 457-463.

Kleesment, A. \& Kurvits, T. 1987. Mineralogy of Tremadoc graptolitic argillites of North Estonia. Oil Shale, 4, 130-138 (in Russian).

Loog, A. 1964. Pakerordi lademe litostratigraafilisest liigestusest avamusel. In VII Eesti Loodusuurijate päeva ettekannete teesid, pp. 82-84. Tartu. 
Loog, A. \& Kivimägi, E. 1968. On the lithostratigraphy of the Pakerort Stage in Estonia. ENSV TA Toim. Keemia Geol., 17, 374-385 (in Russian).

Mange, M. A. \& Maurer, H. F. 1992. Heavy Minerals in Colour. Chapman \& Hall, London.

Mens, K. \& Pirrus, E. 1987. Hiatuses in the Baltic Vendian and Cambrian sections. Proc. Estonian Acad. Sci. Geol., 36, 49-57 (in Russian).

Mens, K., Viira, V., Paalits, I. \& Puura, I. 1989. Cambrian-Ordovician boundary beds at Mäekalda, Tallinn, North Estonia. Proc. Estonian Acad. Sci. Geol., 38, 101-111.

Morad, S. \& Aldahan, A. A. 1986. Alteration of detrital Fe-Ti oxides in sedimentary rocks. Geol. Soc. Amer. Bull., 97, 567-578.

Nicoll, R. S. 1990. The genus Cordylodus and a latest Cambrian-earliest Ordovician conodont biostratigraphy. BMR J. Austral. Geol. \& Geophys., 11, 529-558.

Nicoll, R. S. 1991. Differentiation of Late Cambrian-early Ordovician species of Cordylodus (Conodonta) with biapical basal cavities. BMR J. Austral. Geol. \& Geophys., 12, 223-244.

Nicoll, R. S., Miller, J. F., Nowlan, G. S., Repetski, J. E. \& Ethington, R. L. 1999. Iapetonudus (N. gen.) and Iapetognathus Landing, unusual earliest Ordovician multielement conodont taxa and their utility for biostratigraphy. Brigham Young Univ. Geol. Stud., 44, 27-101.

Popov, L., Khazanovich, K. K., Borovko, N. G., Sergeeva, S. P. \& Sobolevskaya, R. F. 1989. The Key Sections and Stratigraphy of the Phosphate-Bearing Obolus Beds on the North-East of Russian Platform. Nauka, Leningrad.

Puura, I. \& Viira, V. 1999. Chronostratigraphy of the Cambrian-Ordovician boundary beds in Baltoscandia. In Quo vadis Ordovician? (Kraft, P. \& Fatka, O., eds.). Acta Univ. Carolinae Geol., 43, 5-8.

Tjernvik, T. E. 1958. The Tremadocian Beds at Flagabro in South-Eastern Scania (Sweden). Geol. Fören. Stockh. Förhandl., 80, 259-276.

Viira, V., Sergeyeva, S. \& Popov, L. 1987. Earliest representatives of the genus Cordylodus (Conodonta) from Cambro-Ordovician boundary beds of North Estonia and Leningrad Region. Proc. Acad. Sci. ESSR Geol., 36, 145-153.

\title{
Orasoja kihistiku (Tremadocian, Kirde-Eesti) stratotüüp: litoloogia, mineraloogia ja biostratigraafia
}

\author{
Heljo Heinsalu, Dimitri Kaljo, Tiia Kurvits ja Viive Viira
}

Orasoja kihistik koosneb valdavalt heledast aleuroliidist ja peeneteralisest liivakivist, mis vahelduvad Dictyonema kilda vahekihtidega. Seda vaheldust vaadeldakse üleminekuna Türisalu kihistusse. Mineraalidest domineerib põhikivimis kvarts, K-päevakivi on keskmiselt 15\%. Nende, samuti opaaksete ja mitteopaaksete mineraalide suhte ja granulomeetria muutuste alusel jaguneb kihistik kaheks tsükliks, kusjuures neist ülemises on suurem värske mineraalainese osakaal. Lamav Rannu kihistik on jämedateralisem ja sisaldab rohkesti lingulaatide detriiti. Orasoja läbilõikes eristatakse kolm konodontide tsooni ja kaks graptoliitide alamtsooni. Cordylodus lindstromi tsooni algus Rannu kihistiku ülemises osas (seal ilmub ka Iapetognathus sp.) tähistab Kambriumi ja Ordoviitsiumi ladestu piiri. 